\title{
ANALYZING THE PROCESS OF PRODUCTION IN LOGISTICS SUGARCANE MILL: A CASE STUDY
}

\author{
Alexandre Tognoli \\ Universidade do Sagrado Coração (USC) - Brazil \\ E-mail: alextognoli@lpnet.com.br \\ Alessandro Adriano Bodo \\ Universidade do Sagrado Coração (USC) - Brazil \\ E-mail: alessandrobodo@reunion.eng.br \\ Nicholas Luis Braga Sebastião \\ Universidade do Sagrado Coração (USC) - Brazil \\ E-mail:nicholassebastiao@hotmail.com \\ Osmar Corradini \\ Universidade do Sagrado Coração (USC) - Brazil \\ E-mail: osmar.corradine@itelefonica.com.br
}

Submission: 01/05/2011

Accept: 12/06/2011

\begin{abstract}
The objective was to present and analyze the physical arrangement of logistics and production process plant in a sugarcane mill, in order to expose the processes involved, analyzing them more deeply and thus collaborate in a more efficient production. The relevance of this presentation is linked to the benefits that the plant and professionals can get through this work, enabling the development of methods and production alternatives. The research method used was case study based on interviews, on-site observation and document analysis, which was very appropriate as it could examine and cross checking. This work will allow a better understanding of the production process of the logistics of the plant in a sugarcane mill and working with suggestions and methods for more efficient production.
\end{abstract}

Keywords: layout, production process, logistics of production, sugarcane mill.

\section{INTRODUCTION}

In recent decades, major advances in basic research have increased their productivity, and exploiting our wealth of natural resources. This is the time to invest in research and technological development, which seeks alternatives for innovative and efficient strategic planning sustain this pace of commercial development.

This work aims to expose the production process of production logistics in a sugarcane mill and methods for more efficient production and thus meet the high demands of the globalized market. 
This research is a case study with qualitative methodology, which will be based on 3 ways to validate the information, they are: semi-structured interviews, document analysis and observation in place.

\section{LOGISTICS}

The logistics, according to Bovet and Thiagarajan (2000), is the management, control and strategy that involve the flow of raw material to finished product, aiming at the continuous development of service level, aiming to reduce costs, decrease inventory and meet the needs of internal customers.

According to Ballou (2003), has been suggested that a logistics strategy has three objectives: (a) cost reduction, strategy aiming to minimize the variable costs associated with handling and storage, (b) reduction of capital, a strategy directed at minimizing the level of investment in the logistics system, and (c) improved services, strategies that normally recognize that the revenue depends on the level of logistics services provided.

Logistics, according to Lima (2006), Ballou (2003) and Rodrigues and Oliveira (2010), can be divided into the following macro: logistics, supply, production, distribution, and integrated Supply Chain Management (SCM), which can be defined as follows:

a) Logistics supplies: is the branch of logistics business that deals with the flows of raw materials and products for the organization, its purpose being to satisfy the material requirements of the operation. Good management of logistics supply means coordinating the movement of supplies to the operating requirements (BALLOU, 2003);

b) Production Logistics: involves activities from receipt of raw materials, all logistical support to manufacturing and delivery of finished products for shipment (CAMPI, 2008; FARIA; ROBLES, BIO, 2004);

c) Logistic distribution: it starts with the request, dealing with the handling, storage and processing of final orders of the firm, given two types of markets: in the process and users. The in-process (wholesalers and retailers) do not use the product, but offer it for resale. The users directly use the final product. (BALLOU, 2003; BOWERSOX; CLOSS, 2001);

d) Integrated logistics: covers the activities of supply, production and distribution, whose goal is not to reduce inventory shrink, improve levels of control across the material flow in the company, defining the best levels of stock and is the major driving force for organizational transformations. This results in reunification, so that key tasks are transformed into managing the flow of crossfunctional activities, providing a visible "end to end" supply chain logistics from order to delivery (BALLOU, 2003; CHRISTOPHER , 2007; RODRIGUES, OLIVEIRA, 2010); 
e) Supply Chain Management (SCM) can be considered a vision expanded, updated and holistic management of materials, covering the management of the entire production chain from a strategic and integrated manner, describing the administration of the flow of goods and information. The SCM assumes fundamentally that companies should define their competitive strategies and functional through their positions, both as providers and as consumers, within the production chains in which they operate, creating value in the form of products and services to the ultimate consumer (ALVES, 2008; CHING, 2001, GARCIA et al. 2006; SIMCHI-LEVI; KAMINSKY, SIMCHI -LEVI, 2003); and

f) The cost of logistics: they suggest that the costs are segregated into: direct and indirect, fixed, variable and semi-variable, unrecoverable (sunk costs), incremental, or marginal. What will other function is to plan, implement and monitor the entire inventory of entry into and exit process from the point of origin to destination. Each of these costs reveals a unique importance for decision making in logistics (FARIA; COSTA, 2005; BLOOMBERG, LEMAY, HANNA, 2002; ZAGO et al., 2005).

According to Severo Filho (2006), logistics managers must constantly deal with decisions relating to purchasing, production and distribution. He mentions that some of the most important decisions are:

a) How to order: every request for replenishment must specify the amount required, based on expected future demand, supply constraints, existing discounts and costs involved;

b) When ordering: the exact time to issue a new order parameter is determined by the point of order, which depends on the replenishment lead time, demand and the expected level of service desired;

c) How often do you review the inventory levels: inventory levels may be revised continuously or periodically, depending on the technology and costs of this review, among other factors;

d) Where to find stocks: If a company can store its products in more than one installation, location decisions should be taken, for example, keeping finished products in small warehouses close to customers or in a central warehouse, which depends distribution costs, service restrictions, time in which customers agree to wait, time distribution, inventory costs, costs of facilities etc; and

e) How to control the system: the use of performance indicators and monitoring of the operations must be present to support corrective measures and contingency actions, if the logistics system is out of control or operating with low performance. 


\section{CASE STUDY}

The industry throughout Brazil can currently be classified as the most profitable and has received funding from Brazilian and foreign investors and are in a constant modernization, because the production of an environmentally friendly fuel means a prosperous future for the industry and the planet.

The Brazilian sugar and alcohol sector includes industries that produce sugar, alcohol, energy, molasses, among other products, but can also act on any link in the supply chain sector.

This sector is directly related to the cultures of cane sugar, as this is the main feedstock for the production processes mentioned above.

In Illustration 1 can be seen the expansion of ethanol production industries, sugar, the state of São Paulo, where the dark points are the power plants in operation and the yellow dots are plants under construction or planned to enter service soon.

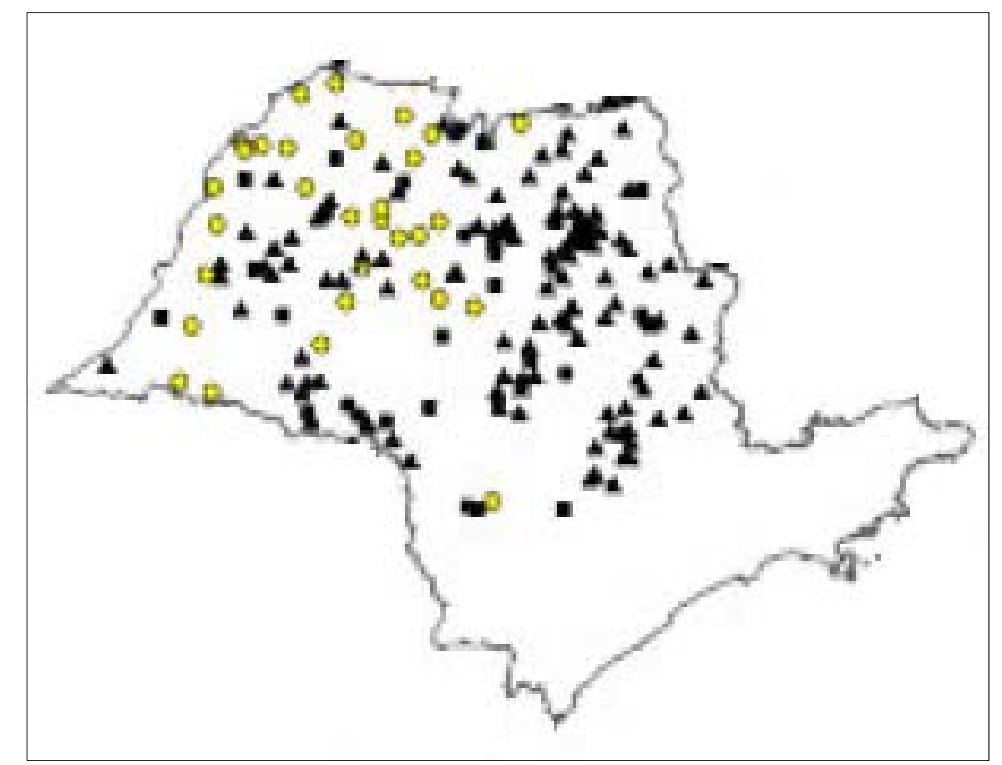

Illustration 1: Map of expansion of the sugar and alcohol

Source: Adapted from Lins e Saavedra (2007)

Most of the plants work with the products, sugar, alcohol and molasses as the market trend may occur a change in the proportion of each devoted to sugarcane production line. Currently this is investing in power generation and production of MDF and HDF from sugarcane bagasse.

According to Lins and Saavedra (2007), Brazil is the largest producer and exporter of sugar and second largest producer of ethanol, accounting for approximately $35 \%$ of world production of ethanol.

The use of cane sugar as a feedstock for the production of sugar and alcohol, coupled with social and environmental factors, confers differential productivity and quality of Brazilian products in the face of foreign alternatives, which make use of 
inputs such as corn or beet sugar, in Tables 1 and 2 values are presented concerning the production of ethanol and sugar in Brazil (Lins; SAAVEDRA, 2007).

Table 1: Data in the industry and the research sample

\begin{tabular}{lrrr}
\hline & $\begin{array}{r}\text { sugar and alcohol } \\
\text { sector }\end{array}$ & Study Sample & $\begin{array}{r}\text { (\%)Study Sample } \\
\text { / Sector }\end{array}$ \\
\hline Processed Cane (ton) & 457.980 .000 & 114.578 .856 & $25,0 \%$ \\
\hline Sugar produced (ton) & 30.629 .827 & 9.204 .904 & $30,1 \%$ \\
\hline alcohol produced (m3) & 17.909 .822 & 4.390 .623 & $24,5 \%$ \\
\hline Anhydrous (m3) & 8.081 .661 & 2.407 .991 & $29,8 \%$ \\
\hline Hydrated (m3) & 9.828 .161 & 1.982 .632 & $20,2 \%$ \\
\hline
\end{tabular}

Source: Adapted from Lins e Saavedra (2007)

Table 2: Comparison of alternative sources for ethanol production

\begin{tabular}{llrcr}
\hline Region & Culture & $\begin{array}{r}\text { Production } \\
\text { cost } \\
\text { (USD/litro) }\end{array}$ & $\begin{array}{c}\text { energy } \\
\text { efficiency }\end{array}$ & $\begin{array}{r}\text { productivity } \\
\text { (liters / ha) }\end{array}$ \\
\hline Brazil & Cane sugar & 0,21 & 8,3 & 6.000 \\
\hline USA & corn & 0,27 & 1,4 & 3.100 \\
\hline Europe & beet & 0,76 & 1,9 & 5.000 \\
\hline
\end{tabular}

Source: Adapted from Lins e Saavedra (2007)

The sector is organized into three levels: the cultivation of cane sugar production base of the byproducts of sugar cane and marketing and distribution of the finished product. Currently many industries are outsourcing the process of cultivation and distribution of the finished product, thus focusing on the production of by-products.

The supply chain of this sector can be depicted as Illustration 2, which is presented in the links of production, since the past decades also the industries owned farms, where it was cultivated sugar cane and even distribution and consequently could lose the focus of the business.

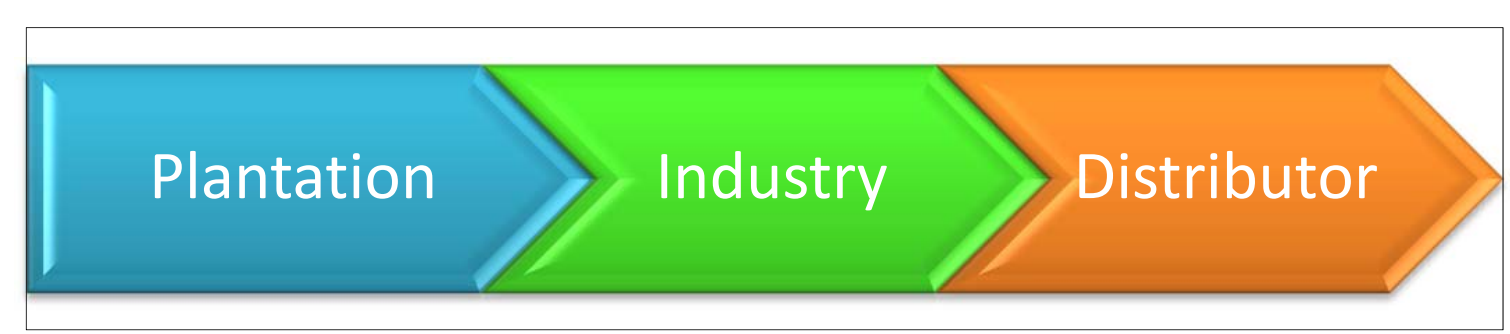

Illustration 2: Flow supply chain

Emphasis will be placed from now to the production process and logistics of producing an industry that produces sugar, ethanol, molasses and energy within the state of São Paulo. 
The process of transforming sugar cane begins with the grinding, in which the juice is extracted from the bagasse, which will go through various stages of physical and chemical processing until you get one of two end products: sugar or ethanol, Illustration 3 shows the simplicity of how the production process.

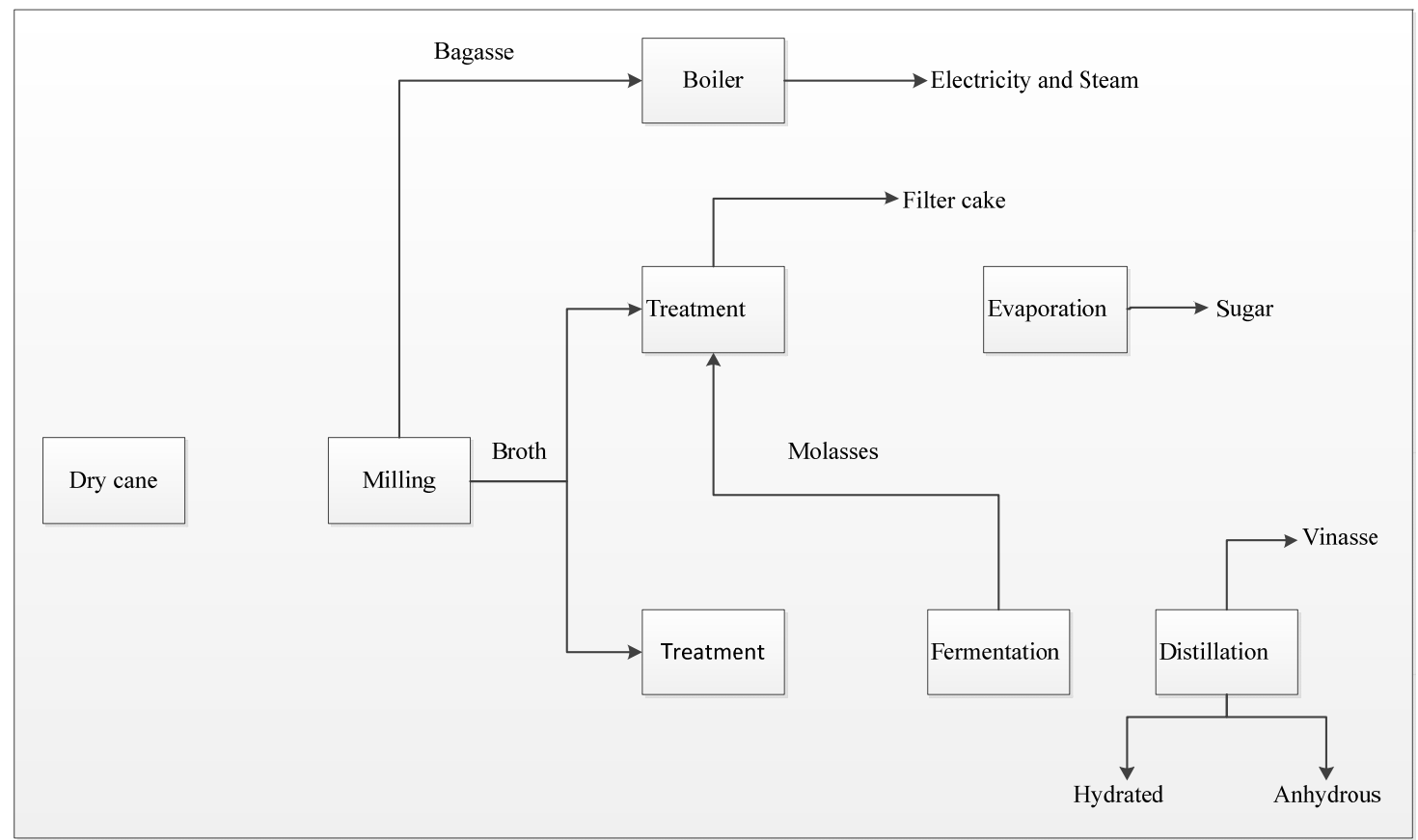

Illustration 3: Simplified procedure for ethanol production Source: Smeets et al., (2006)

For illustration of the production process can occur at three production logistics to worry about managing some variables: productivity, efficiency, cost, time, technology, manpower, routing, etc.

To manage these variables is necessary to create dynamic processes of analysis, because the production process can be affected by time and distance of transportation of cane sugar and even by weather problems.

In Figure 4 we can observe how a plant can have the equipment comprising a greater productive efficiency, in this example should be a concern in distributing the equipment to take a continuous production line which will allow a more flexible maintenance of equipment and even observe the same equipment which fatigue.

The equipment being arranged in a linear fashion, ie, to allow the execution of each process sequentially, can help in the definition of improved productivity.

The logistics of production can also contribute to better analyze the position of the dispatch centers of the base products of cane sugar, to enable greater productivity in the marketing of products, using the modal road and rail. 
Two other by-products from the sugar cane is the mud and slop, which can be utilized for irrigation of sugarcane fields, but that these products must be stored in tanks near the irrigation areas.

To do this you must use the duct modal road, because it could reach distant points of the plant is a low cost of transportation and maintenance, the same modal can be installed outdoors or be underground, which may protect you from elements of time and without affecting the availability of crop fields.

Energy production will serve at first to supply its own power plant and a second phase to the distribution for an energy company, but for this there must be a prior study of where to install the substation.

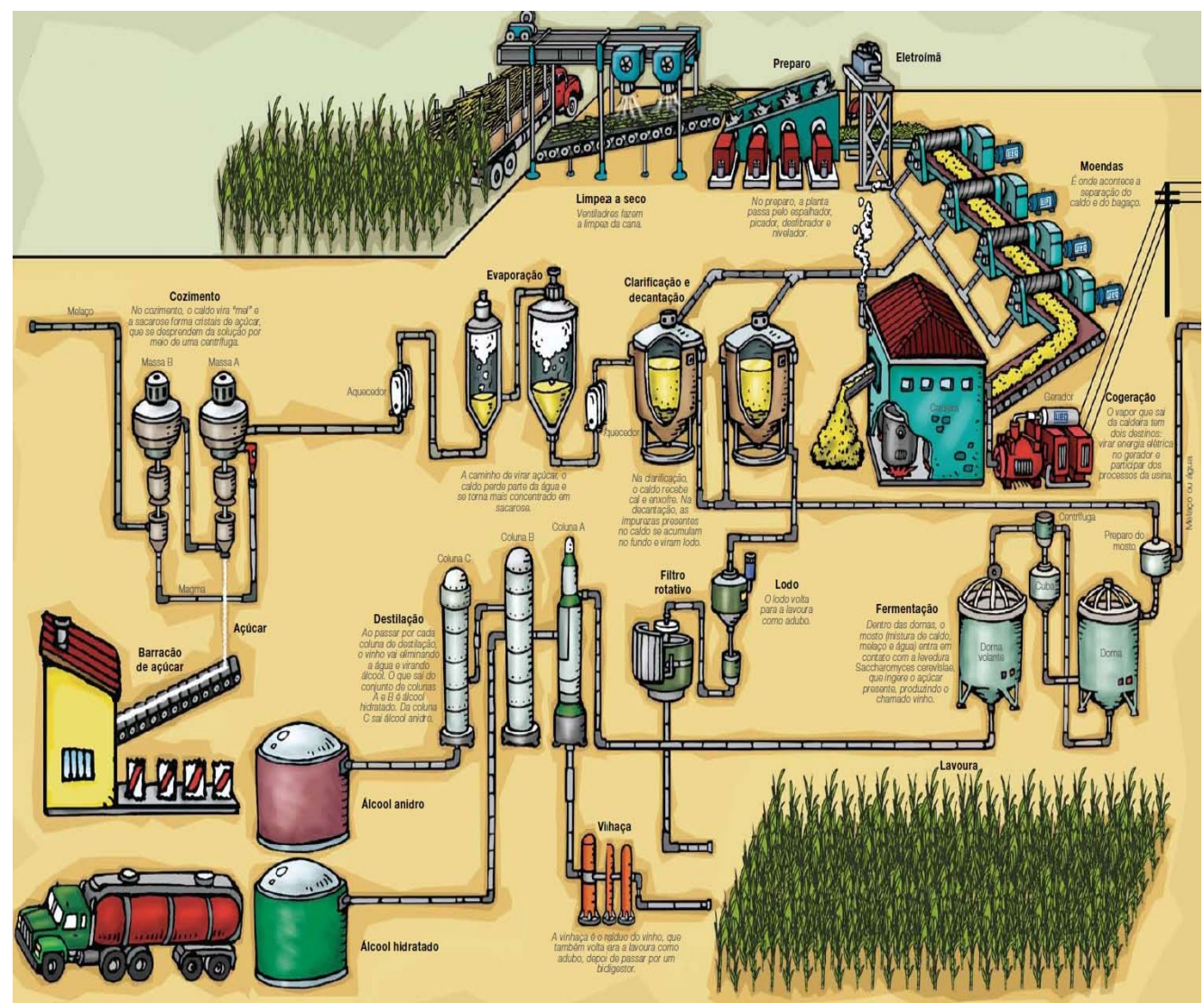

Illustration 4: Plant inside Source: WEG, (2006)

In Illustration 5, is shown in more detail the production of sugar and ethanol, which can observe the amount of equipment that are necessary for the operation of a plant sugar cane.

In Illustration 5, one can also observe the total number of processes that occur during the production of by-products the basis of cane sugar, which account for approximately 11 processes and that may allow the derivation of products such as sugar, ethanol, energy, molasses, vinasse, silt, swings from sugarcane bagasse, among others, thereby increasing productivity and profit. 
DOI: 10.14807/ijmp.v2i1.27

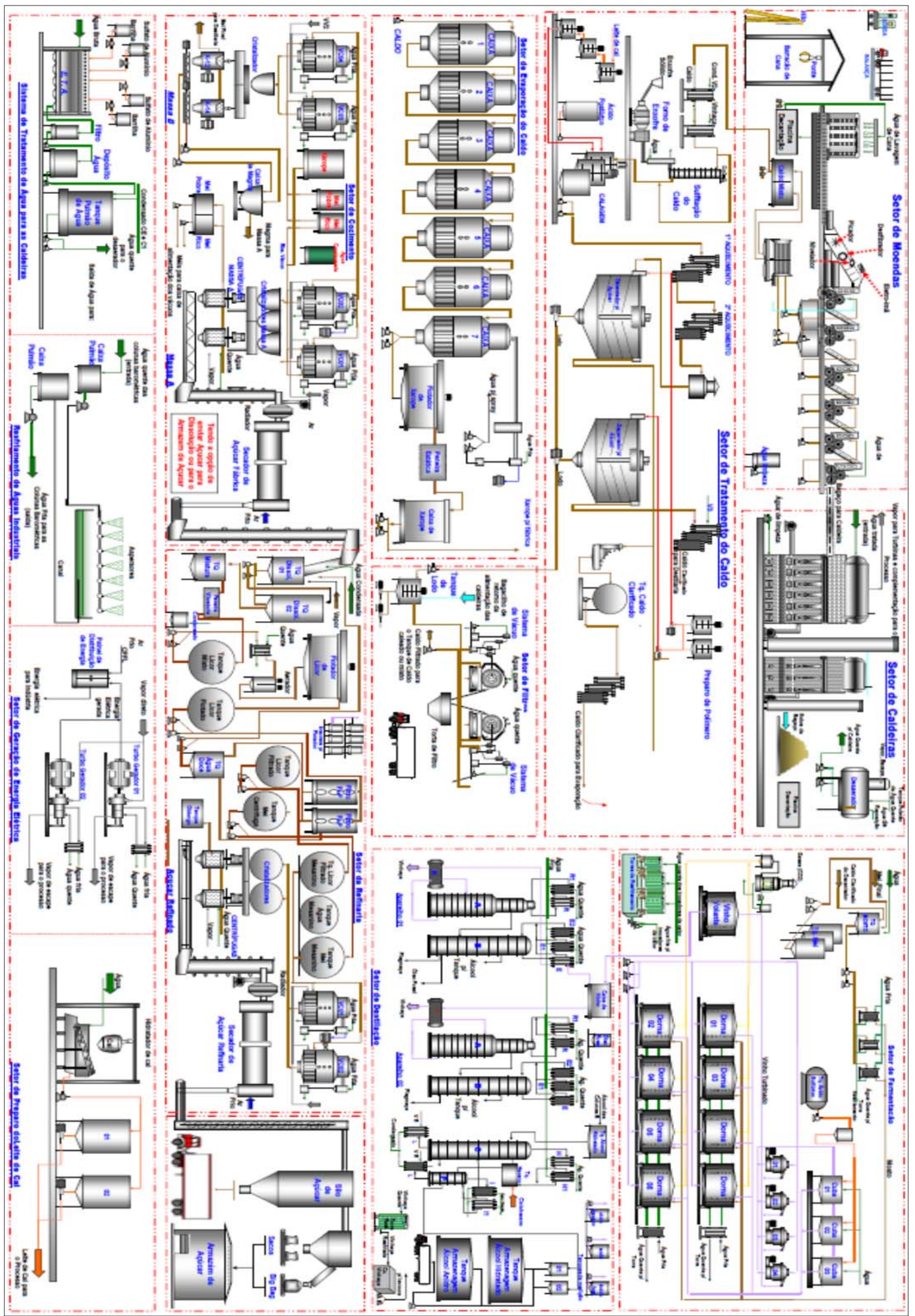

Illustration 5: Process Flow Diagram - Crystal Sugar / Refined and Ethanol Source: Not available, (2006) 


\section{FINAL THOUGHTS}

What we can observe is that the production logistics in the production process of ethanol and sugar is a very important purpose because it will monitor the entire process, noting the times of scheduled maintenance shutdown.

You will also see if there was breakdown of equipment, if the breaks were due to fatigue of the material or wrong operation and whether it breaks or not caused loss of productivity. Since the loss of productivity cannot be observed at first, because in some cases the production time is compensated.

But if this drop is constant and become something it is not worked in the sum total of productivity shifts may occur as an imbalance in the production times each shift and generating a risk.

The logistics of production will also work the physical layout of the unit, allowing time to study the replacement of equipment, movement of raw materials, production time, risks of accident, etc.

It might be noted that the theories studied during the preparation of the work helped to identify potential problems or flaws in the production process of the company studied.

The logistics of production is greatly affected the logistics of supplies, because it will be responsible for acquiring raw materials, i.e. from the input to the production that will support the production, i.e., oil, machinery, parts replacement.

It will suffer the influence of logistics distribution is poorly designed as to distribution of the scripts, formulation of cost of sales and distribution, and miscalculated the time of delivery of the finished product.

It will also influence the supply and distribution logistics, if it occurs some unexpected production stop, schedule preventive maintenance on an inappropriate moment, which may generate increased levels of raw material for grinding and consequently the creation of a bottleneck, if the storage facility does not have a large capacity, there may be a lack of trucks to collect the cane sugar cane field.

The distribution will generate a lack of product for delivery and therefore payment of a fine for lack of it, will affect the reliability to the customer, increased sales and distribution costs, etc.

\section{REFERENCES}

\section{ALVES, A. S. (2008) Ferramentas de Supply Chain Management para a} otimização de estoques. Disponível em:

$<$ http://www.administradores.com.br/producao_academica/ferramentas_de_supply_chai n_management_para_a_otimizacao_de_estoques/994/>, acessado em: 29 ago 2008.

BALLOU, R. H. (2003) Business logistics: supply chain management. 5 ed. New Jersey: Prentice Hall. 
BLOOMBERG, D. J.; LEMAY, S.; HANNA, J. B. (2002) Logistics. New Jersey: Prentice Hall.

BOVET, D. M.; THIAGARAJAN, S. (2000) Logística orientada para o cliente. HSM Management, São Paulo, ano 3, n. 18, p. 122-128, jan./fev.

BOWERSOX, D. J.; CLOSS, D. J. (2001) Logística empresarial: o processo de integração da cadeia de suprimento. São Paulo: Atlas.

CAMPI, T. (2008) Custos da cadeia logística e logística reversa. Disponível em: $<$ http://www.escience.unicamp.br/lalt/admin/publicacoes/documentos/publicacao_570 aula09.pdf $>$. Acessado em: 05 jul 2008.

CHING, H. Y. (2004) Gestão de estoques na cadeia de logística integrada: Supply chain. 2 ed. São Paulo: Atlas.

CHRISTOPHER, M. (2007) Logística e gerenciamento da cadeia de suprimentos. 2 ed. São Paulo: Pioneira.

FARIA, A. C.; ROBLES., L. T.; BIO, S. R. (2004) Custos logísticos: discussão sob uma ótica diferenciada. In: CONGRESSO BRASILEIRO DE CUSTOS, 11, 2004, Porto Seguro. Anais... Porto Seguro: Fundação VISCONDE DE CAIRU.

FARIA, A. C.; COSTA, M. F. G. (2005) Gestão de custos logísticos. São Paulo: Atlas.

GARCIA, E. S.; REIS, L. M. T. V.; MACHADO, L. R.; FERREIRA FILHO, V. J. M.

(2006) Gestão de estoques: otimizando a logística e a cadeia de suprimentos. Rio de Janeiro: E-papers.

LIMA, M. P. (2006) Custos logísticos: uma visão gerencial. Coppead, 1998. Disponível em: $<$ http://www.coppead.ufrj.br/pesquisa/cel/new/fs-public.htm. $>$. Acessado em: 17 jul 2006.

LINS, C.; SAAVEDRA, R. Sustentabilidade corporativa no setor sucroalcooleiro brasileiro. Rio de janeiro, FBDS, 2007.

RODRIGUES, P. C. C.; OLIVEIRA, O. J. Engineering-to-order versus make-to-stock Strategy: an analysis at two printing companies. Independent Journal of a Management \& Production, v. 1, n. 1, p. 1-23, 2010.

SEVERO FILHO, J. Administração de logística integrada: materiais, PCP e marketing. 2 ed. Rio de Janeiro: E-papers, 2006.

SIMCHI-LEVI, D.; KAMINSKY, P.; SIMCHI-LEVI, E. (2003) Cadeia de suprimentos: Projeto e Gestão. São Paulo, Bookman.

SMEETS, E.; JUNGINGER, M.; FAAIJ, A.; WALTER, A.; DOLZAN, P.

Sustainability

of Brazilian bio-ethanol. Report: NWS-E-2006-110, ISBN: 90-8672-012-9, 2006.

WEG. Usina por dentro. Disponível em: $<$ http://www.weg.net/acucar-ealcool/usina_por_dentro.html>. Acessado em: 12 mai 2011.

ZAGO, C. A.; ADAM, C.; NORO, G. B.; OLIVEIRA, J. H. R. (2005) Análise do processo logístico: o caso Bunge Santa Maria. In: SIMPÓSIO DE ENGENHARIA DE PRODUÇÃO, 12., 2005, Bauru. Anais... Bauru: FEB/UNESP. 